\title{
Food value and basic parasitosis of fish used in food by indigenous populations of Yakutia
}

\author{
Terenty Platonov ${ }^{1}$, Konstantin Stepanov ${ }^{1}$, Ayan Nyukkanov $^{1}$, Natalia Kuzmina ${ }^{1, *}$, and Anna Gorokhova ${ }^{2}$ \\ ${ }^{1}$ Yakut State Agrarian Academy, 677007 Yakutsk, Russia \\ ${ }^{2}$ North Eastern Federal University, 677000 Yakutsk, Russia
}

\begin{abstract}
The article presents the results of studies of nutritional value and the degree of infection with parasitoses of Siberian vendace (Coregonus sardinella Vallenciennes, 1848) and Yakut crucian carp (Carassius carassius jacuticus Kirillov, 1972). By the amount of protein, the Siberian vendace is classified as medium-protein, in terms of fat content, it is especially fatty fish and of high calories. It has been established that a distinctive feature of the Yakut crucian carps compared to European ones is high fat content (up to $10 \%$ versus $2.5 \%$ ), high content of polyunsaturated fatty acids, macro- and microelements, vitamins, and have high energy value. The most common parasitic diseases of the crucian carp and vendace, affecting the quality and appearance of the fish, are myxosporidioses caused by Myxobolus, digramosis and phylometroidosis, the negative impact on the quality of which depends on the parasite infection intensity.
\end{abstract}

\section{Introduction}

The Siberian vendace (Coregonus sardinella Vallenciennes, 1848) in the rivers of Yakutia leads a semi-passage way of life, it is found in all rivers flowing into the Laptev Sea (the Anabar, Olenek rivers), the East Siberian Sea (the Lena, Yana, Indighirka, Kolyma rivers). For feeding it uses the shelves of these seas. In the fourth year of life it reaches puberty. The first spawning run occurs in July-August, the second - in September-October. The commercial age of the vendace is from 4+ to 9+ years, the length is from 220 to $360 \mathrm{~mm}$, the weight is 150 to $330 \mathrm{~g} \mathrm{[1]}$.

The nutritional and biological value of the Siberian vendace in Yakutia is understudied. Thus, some studies of the chemical composition, including mineral content were investigated [2]. An important role in determining the quality of fish products is played by infection of fish with parasitoses. Intensive infection with certain parasites reduces the fatness and quality of fish products in some cases and makes the fish unsuitable for food use.

In the past, the Yakut crucian carp was the main food for the Yakuts of Central Yakutia, the Vilyui region, which saved the Yakut population in difficult times of food shortages [3].

The Yakut crucian carp (Carassius carassius jacuticus Kirillov, 1972) is a special subspecies of goldfish and is officially named as Kirillov Yakut crucian (Carassius Gacuticus Kirillov) after the name of the first scientist who described the Yakut crucian carp F.N. Kirillov, Doctor of Biological Sciences [4].

Lake Nigili is one of the largest on the Central Yakut Plain. The area of the lake's water mirror is $118.3 \mathrm{~km}^{2}$, the catchment area is $1029 \mathrm{~km}^{2}$, the length of the lake is
$32.9 \mathrm{~km}$, the width is about $2.3-5.8 \mathrm{~km}$, and in some places the depth reaches 7-9 $\mathrm{m}$. The Nigili crucian, recognized by its taste as the best in Yakutia, enjoys the greatest demand among the population in comparison with the crucian carp caught from other lakes. The annual catch reached 345 tonnes, not taking amateur fishing into account [1]. The uniqueness of taste and the great demand for the crucian carp of Nigili among the local consumers were the basis of these studies.

Given this and the fact that the Siberian vendace and the Yakut crucian carp occupy one of the first places in the diet of northerners, we set the goal to study the nutritional and biological value of the Siberian vendace and the Yakut crucian carp in order to develop modern technologies for the production of fish products from these fish.

Fish of the autumn-winter catch of 2017 of the Indighirka river of the Republic of Sakha (Yakutia), quick-frozen at a temperature not higher than $-30{ }^{\circ} \mathrm{C}$ in a modular installation for freezing products (MUZ-07-10), followed by storage in glaciers and freezers at a temperature not higher than $-15{ }^{\circ} \mathrm{C}$ were selected for research.

For analysis, samples were taken from 3 fish by separation into fillet and flank prepared according to standard methods as per GOST 31339-2006.

Amino acid score was calculated according to the formula: (mg AA in $1 \mathrm{~g}$ of the studied protein)/(mg AA in $1 \mathrm{~g}$ of target protein $\mathrm{x}$ 100) [5].

In order to study the most common invasive diseases of the vendace of the Indigirka river, we studied 57 specimens of fish using the method of complete parasitological autopsy. The collection and processing of parasitological material was carried out by standard

* Corresponding author: lukinanatalia58@gmail.com 
methods [6]. The type of parasite, the extent and intensity of the invasion were determined.

To identify the invasive diseases of the crucian carp from the lakes of the Central Yakut plain, which affect the commercial quality of fish, we examined 45 specimens of the crucian carp of Nigili lake in 2018 using the full parasitological autopsy method. The collection and processing of parasitological material was carried out by standard methods [7]. The type of parasite, the extent and intensity of the invasion were determined.

\section{Results and discussion}

Morphological composition of the vendace. The live weight averaged $366.8 \pm 11.00 \mathrm{~g}$, fillet mass yield was $202.3 \pm 5.40 \mathrm{~g}(55.13 \%)$, waste was $164.50 \pm 2.70 \mathrm{~g}$ (44.97\%), including viscera $20.4 \pm 1.10 \mathrm{~g}(12.4 \%)$, heads $32.0 \pm 2.10 \mathrm{~g}(19.5 \%)$, fins $48.4 \pm 3.00 \mathrm{~g}$ $(29.4 \%)$, scales $21,7 \pm 1.60 \mathrm{~g}(13.2 \%)$, skins $19.7 \pm 1.50 \mathrm{~g}(12.0 \%)$, bones $22.2 \pm 1.80 \mathrm{~g}(13.5 \%)$.

As a result of the studies (Table 1), fillet and flank of the Siberian vendace are classified as medium protein $(10-15 \%)$ by the amount of protein. Thus, the protein content in fillet was $15.37 \pm 0.007$, in flank $14.88 \pm 0.004 \%$. According to the fat content in flank $(25.25 \pm 0.049 \%)$, the vendace is a particularly fatty variety of fish (more than $15 \%$ of fat). As a result of a high content of protein and fat, the vendace is a highcalorie food product (more than 200-300 kcal).

Table 1. The chemical composition and energy value of vendace filet and flank, in wet weight

\begin{tabular}{|c|c|c|c|}
\hline Indicators & \multirow{2}{*}{ Unit } & \multicolumn{2}{|c|}{ Quantity } \\
\cline { 3 - 4 } & & in filet & in flank \\
\hline Water & $\%$ & $74.61 \pm 0.015$ & $80.25 \pm 0.049$ \\
\hline Proteins & $-\langle »-$ & $15.37 \pm 0.007$ & $14.88 \pm 0.044$ \\
\hline Fats & $-\langle »-$ & $9.08 \pm 0.010$ & $25.25 \pm 0.049$ \\
\hline Ash & $-\langle »-$ & $2.37 \pm 0.003$ & $0.78 \pm 0.001$ \\
\hline Energy value & $\mathrm{Kcal} / 100 \mathrm{~g}$ & 143 & 286 \\
\hline
\end{tabular}

The content of macro- and microelements. The research results and their analysis showed that the highest content of macro- and micronutrients was observed in flank (Table 2).

The content of heavy metals in fillet does not exceed the maximum allowable concentration (MAC), while in flank the contents of lead are 0.7 times higher, mercury 0.5 times higher, cadmium -0.1 times higher than maximum allowable concentration (Table 2).

Exceeding the maximum allowable concentration of heavy metals may depend on their distribution in the environment, including in water bodies.

Studies of amino acid composition showed that the Siberian vendace contains all the essential amino acids.
Essential amino acids such as leucine, lysine also prevail, and their total level in flank is higher $(28.56 \mathrm{~g} / 100 \mathrm{~g})$ compared to fish fillet $(26.83 \mathrm{~g} / 100 \mathrm{~g})$.

The analysis of replaceable amino acids showed that alanine, cystine, and arginine dominate in quantitative content. They account for 80.03 to $93.75 \mathrm{~g} / 100 \mathrm{~g}$ in fish fillet and flank of the total amount of replaceable amino acids, respectively.

Table 2. The content of macro- and micronutrients in filet and flank of the vendace, in wet weight

\begin{tabular}{|c|c|c|c|}
\hline \multirow[t]{2}{*}{ Indicators } & \multirow[t]{2}{*}{ Unit } & \multicolumn{2}{|c|}{ Quantity } \\
\hline & & in filet & in flank \\
\hline \multicolumn{4}{|c|}{ Macronutrients } \\
\hline Calcium & $\mathrm{mg} / 100 \mathrm{~g}$ & $37.38 \pm 0.036$ & $49.73 \pm 0.207$ \\
\hline Phosphorus & $-\langle\langle\rangle-$ & $198.07 \pm 0.113$ & $236.65 \pm 0.647$ \\
\hline Magnesium & $-\langle\langle\rangle-$ & $43.40 \pm 0.036$ & $55.36 \pm 0.199$ \\
\hline Potassium & $-\langle\langle\rangle-$ & $223.55 \pm 0.083$ & $252.49 \pm 0.484$ \\
\hline \multicolumn{4}{|c|}{ Micronutrients } \\
\hline Ferrum & $\begin{array}{l}\mathrm{mg} / \\
100 \mathrm{~g}\end{array}$ & $13.49 \pm 0.012$ & $18.61 \pm 0.088$ \\
\hline Manganese & $-\langle\langle\rangle-$ & $0.79 \pm 0.002$ & $0.98 \pm 0.003$ \\
\hline Zinc & $-\langle\langle\rangle-$ & $14.24 \pm 0.015$ & $19.45 \pm 0.088$ \\
\hline Copper & $-\langle\langle\rangle-$ & $0.35 \pm 0.001$ & $0.48 \pm 0.003$ \\
\hline Fluorine & $\mathrm{mcg} / 100 \mathrm{~g}$ & $2.00 \pm 0.003$ & $2.76 \pm 0.012$ \\
\hline Chrome & $-\langle\langle\rangle-$ & $34.52 \pm 0.030$ & $44.16 \pm 0.160$ \\
\hline Molybdenum & $-\langle\langle\rangle-$ & $10.83 \pm 0.009$ & $14.30 \pm 0.059$ \\
\hline Cobalt & $-\langle\langle\rangle\rangle-$ & $108.26 \pm 0.102$ & $142.99 \pm 0.583$ \\
\hline Iodine & $-\langle\langle\rangle-$ & $12.36 \pm 0.009$ & $15.25 \pm 0.049$ \\
\hline Selenium & $-\langle\langle\rangle-$ & $33.04 \pm 0.027$ & $42.11 \pm 0.155$ \\
\hline \multicolumn{4}{|c|}{ Heavy metals } \\
\hline Lead & $\mathrm{mg} / \mathrm{kg}$ & $1.02 \pm 0.001$ & $1.39 \pm 0.006$ \\
\hline Mercury & $-\langle\langle\rangle-$ & $0.11 \pm 0.009$ & $1.14 \pm 0.005$ \\
\hline Cadmium & $-\langle\langle\rangle-$ & $0.11 \pm 0.009$ & $1.14 \pm 0.004$ \\
\hline
\end{tabular}

Note. MAC: lead - $1.0 \mathrm{mg} / \mathrm{kg}$; mercury - 0.6; cadmium $0.2 \mathrm{mg} / \mathrm{kg}$ (Sanitary regulations and norms 2.3.2.560-96).

The total content of linoleic and linolenic acids in the studied samples is 0.37 and $0.53 \mathrm{~g} / 100 \mathrm{~g}$ of lipids related to biologically active polyunsaturated fatty acids and which are an integral part of vitamin F (essential fatty acids), which plays an important role in the biochemical processes of the body.

Flank differs from fillet according in the content of fatty acids. In flank of the vendace, a high ratio of polyunsaturated fatty acids to saturated (more than 1) was revealed, which indicates good biological effectiveness.

First of all, fillet and flank of the vendace are rich in a complex of fat-and water-soluble vitamins. It was found that the content of fat-soluble vitamin D in flank of the vendace is slightly higher $(20.97 \mu \mathrm{g} / 100 \mathrm{~g})$ compared to fillet $(15.47 \mu \mathrm{g} / 100 \mathrm{~g})$. Similar differences are noted with individual comparison. They have a lot of B vitamins, little vitamin D and B9 compared to the published data [8, 9].

Table 3. The output of fillet and waste of the Yakut crucian carp

\begin{tabular}{|l|c|c|c|c|c|c|c|}
\hline \multicolumn{1}{|c|}{ Reservoir } & Unit & Mass of the Crucian Carp & Fillet & Viscera & Head & Float & Scales \\
\hline Lake Nigili of the & $\mathrm{g}$ & 290.00 & 125.20 & 76.00 & 62.20 & 9.30 & 17.00 \\
Kobyai region & $\%$ & 100 & 43.2 & 26.2 & 21.4 & 3.2 & 5.9 \\
\hline
\end{tabular}


Table 4. Biochemical composition of the crucian carp in Yakutia, Nigili lake (in wet weight) [6]

\begin{tabular}{|c|c|}
\hline Components & Indices \\
\hline \multicolumn{2}{|c|}{ Chemical composition } \\
\hline Water. \% & 68.6 \\
\hline Proteins. \% & 16.4 \\
\hline Fats. $\%$ & 11.0 \\
\hline Carbohydrate. $\%$ & 0.90 \\
\hline Ash. $\%$ & 1.05 \\
\hline Energy value. kcal/100 g & 159.00 \\
\hline \multicolumn{2}{|c|}{ Irreplaceable: } \\
\hline Amino acids. mg/kg & 54.50 \\
\hline - leucine & 11.60 \\
\hline - lysine & 13.90 \\
\hline - methionine & 3.00 \\
\hline - tryptophan & 1.91 \\
\hline \multicolumn{2}{|l|}{ Replaceable: } \\
\hline - tyrosine & 4.95 \\
\hline - cystine & 1.90 \\
\hline \multicolumn{2}{|c|}{ Fatty acid. \% } \\
\hline Saturated & 3.45 \\
\hline Monounsaturated & 4.47 \\
\hline Polyunsaturated: & 3.08 \\
\hline$-\mathrm{C}_{18: 2}$ & 0.62 \\
\hline$-\mathrm{C}_{18: 3}$ & 0.05 \\
\hline$-\mathrm{C}_{20: 4}$ & 0.14 \\
\hline \multicolumn{2}{|c|}{ The content of macronutrients. $\mathrm{mg} / 100 \mathrm{~g}$} \\
\hline Calcium & 10.90 \\
\hline Potassium & 248.40 \\
\hline Magnesium & 18.60 \\
\hline Sodium & 86.30 \\
\hline Phosphorus & 198.40 \\
\hline Chlorine & 102.90 \\
\hline \multicolumn{2}{|c|}{ The content of trace elements } \\
\hline Ferrum. mg/100 g & 6.20 \\
\hline Manganese. $\mathrm{mcg} / 100 \mathrm{~g}$ & 34.80 \\
\hline Copper. mcg/100 g & 170.60 \\
\hline Zinc. $\mathrm{mg} / 100 \mathrm{~g}$ & 5.60 \\
\hline Fluorine. $\mathrm{mcg} / 100 \mathrm{~g}$ & 116.90 \\
\hline Cobalt. mcg/100 g & 8.94 \\
\hline Iodine. $\mathrm{mcg} / 100 \mathrm{~g}$ & 76.80 \\
\hline Selenium. $\mathrm{mcg} / 100 \mathrm{~g}$ & 14.87 \\
\hline Lead. $\mathrm{mg} / \mathrm{kg}$ & 0.10 \\
\hline Cadmium. mg/kg & 0.05 \\
\hline Mercury. $\mathrm{mg} / \mathrm{kg}$ & 0.03 \\
\hline \multicolumn{2}{|c|}{ Vitamins } \\
\hline A. $\mathrm{mg} / 100 \mathrm{~g}$ & 2.60 \\
\hline D. $\mathrm{mcg} / \mathrm{kg}$ & 2.50 \\
\hline $\mathrm{B}_{6 .} \mathrm{mg} / \mathrm{kg}$ & 3.80 \\
\hline $\mathrm{B}_{12 .} \mathrm{mcg} / \mathrm{kg}$ & 4.00 \\
\hline H. $\mathrm{mcg} / 100 \mathrm{~g}$ & 4.00 \\
\hline PP. mg/100 g & 4.60 \\
\hline $\mathrm{B}_{3} . \mathrm{mg} / \mathrm{kg}$ & 3.90 \\
\hline $\mathrm{B}_{2} . \mathrm{mg} / \mathrm{kg}$ & 1.50 \\
\hline $\mathrm{B}_{1} . \mathrm{mg} / \mathrm{kg}$ & 2.90 \\
\hline Bc. mcg/100 g & 4.80 \\
\hline E. $\mathrm{mg} / \mathrm{kg}$ & 4.00 \\
\hline
\end{tabular}

To study the nutritional and biological value of the crucian carp, 5 individuals of each sex of the IV-V (3-5 years) age groups were selected, as individuals of these groups are actively spawning, as a result of which the accumulation of nutrients occurs much faster than in old and young individuals, and they occupy the largest percentage in industrial catch.
The data presented in Table 3 indicate that for large crucian carp the yield of fish products without the use of entrails is only up to $43.2 \%$, and for small - up to $57.5 \%$. Therefore, it is necessary to develop technologies for the production of fish products with the inclusion of viscera, which will increase the yield of edible parts to $93.2 \%$ and increase the efficiency of production of fish products from the Yakut crucian carp [8].

A distinctive feature of the Yakut crucian carp compared to European ones is its high fat content (up to $10 \%$ versus $2.5 \%$ ), high content of polyunsaturated fatty acids, macro- and microelements, vitamins (Table 4). Therefore, they have a high energy value.

According to our studies, the most common invasive diseases of the Indighirka vendace are: myxosporidiosis tubercle (peptic ulcer) disease, chloromycosis (jaundice); cestodes - diphyllobothriasis; scrapers - neoechinorinhoz.

Myxosporidia, being parasites of a wide variety of organs and tissues of fish, in some cases cause acute diseases that end in the death of the host. Mucous sporozoids cause great damage to the national economy by reducing the quality of fish as a food product, which leads to the rejection of large batches of catch. Currently, myxosporidioses are widespread in the fishing reservoirs of Yakutia and cause significant economic damage to the economy of the Republic.

Tuberous or peptic ulcer disease is caused by Henneguya zschokkei myxosporidia, which are parasitic in the whitefish muscles. According to our data, the extent of invasion of Henneguya zschokkei in the vendace was $36.8 \%$.

Chloricomycosis or whitefish jaundice is caused by sporozoans of Chloromyxum coregoni and is characterized by changes in the gallbladder. In the study of the vendace we have repeatedly found a huge number of spores in the gallbladder with prevalence of $19.2 \%$.

In migratory whitefish, we noted parasitism of plerocercoids of two species of cestodes of the Diphyllobothrium. The plerocercoids of the loon tapeworm (D. ditremum) were found in $56.1 \%$ with infection intensity of 2-8 samples of the vendace, plerocercoids of a gull tape worm (D. dendriticum) $5.2 \%$, infection intensity of 1-2 samples.

Echinorinchiasis is a disease caused by Neoechinorhynchus rutili proboscis worms in the intestines of salmon and whitefish. We noted a largescale infection of the vendace with echinorinhosis with prevalence of $28.0 \%$, infection intensity 2-7 samples.

According to the researchers, 37 species of parasites were identified in the crucian carp of lakes of the Central Yakut plain. Of them, 19 were protozoa, 6 were monogenes, 2 were cestodes, 4 were trematodes, 2 were nematodes and proboscis worms, and 1 was leech and parasitic crustacean [10], among which there are no invasions that pose a danger to humans.

However, not all of them are equally harmful to their host and prevent the use of affected fish for food. Most of the parasites recorded in the crucian carp of these lakes do not affect the commercial quality of fish products [11]. According to our observations, such invasive diseases as myxosporidiosis, digramosis and

\footnotetext{
* Corresponding author: lukinanatalia58@gmail.com
} 
phylometroidosis most negatively affect the quality of the crucian carp.

Myxosporidia of Myxobolus, localized in the form of cysts ranging in size from $0.5-10 \mathrm{~mm}$ on the gill lobes, muscles, abdominal cavity and on the serous membrane of the intestine, depending on the infection intensity, negatively affect the shelf life and appearance of the fish. According to our studies, the contamination of the crucian carp with myxospridiosis is $64.5 \%$, of which $10.4 \%$ with infection intensity negatively affect the quality of the fish.

One of the widespread invasive diseases of the crucian carp is digramosis caused by plerocercoids of the Ligulidae Digramma interrupta of Ligulidae. They parasitize in the abdominal cavity and cause atrophy of the internal organs, infertility, often rupture of the abdominal wall and death of the fish. The plerocercoids are large belt-shaped helminths of white or slightly yellowish color, reaching $25-50 \mathrm{~cm}$ in length and $1-1.5 \mathrm{~cm}$ in width.

The disease is recorded everywhere in the lakes where the crucian carp lives. Most fish infected by plerocercoids and detected during fishing in water bodies were at the age of 2-5 years. The prevalence depending on the fishing season reaches 1-50 \% with infection intensity of 1-3 helminths. Digramosis outbreaks are seasonal and occur in spring and summer. The negative effect of helminth on the crucian carp is reduced to a mechanical effect on internal organs, which causes intoxication of the host organism with metabolic products. We noted hydremia of muscle tissues and depletion in fish, which affect the nutritional value of fish.

Phylometroidosis is a nematode disease of cyprinids; the causative agent is the nematode Philometroides sanguinea. Females $8-12.5 \mathrm{~cm}$ long of bright red color parasitize in scaly pockets, under the skin of the caudal fins and muscle tissue. Males of white color, $0.2-0.3 \mathrm{~cm}$ long, parasitize in the wall of the swimming bladder, in the kidneys and gonads.

The effect of the infection on the commercial quality of the crucian carp depends on the intensity of infection, while the fish are depleted, the skin is hyperemic, scales around the head, on the back, sides and abdomen are often absent, red nodules are observed from under the scales. In spring and autumn, we found infection under the skin of the caudal fins and scaly pockets females of the red colour in $43.7 \%$ of cases with the infection intensity of 3-27 samples.

The most common parasitic diseases of the crucian carp of the Central Yakut plain, affecting the quality and appearance of fish, are myxosporidioses caused by Myxobolus, digramosis and phylometroidosis. The negative impact on the quality of the crucian carp depends on the infection intensity of the parasite.

\section{Conclusion}

In the Siberian vendace of the autumn-winter catch from the Indighirka river of the Republic of Sakha (Yakutia), it was found that in terms of protein content it belongs to medium-protein, in terms of fat content - to especially fatty varieties of fish and high-calorie food products, according to the content of macro- and microelements and vitamins, the vendace has a high biological value.

The high nutritional and biological values of the Siberian vendace and the Yakut crucian carp make them a valuable food product for providing the body of the inhabitants of the northern regions with the necessary amount of nutrients, including biologically active substance during a harsh and long winter [10].

Myxosporidioses - tubercular (peptic ulcer) disease, whitefish chloricomycosis (jaundice), are widespread parasitic diseases of the Indighirka vendace affecting the quality and appearance of the fish. Infection of the vendace with plerocercoids of gull tapeworm (D. dendriticum) is of great epizootological and epidemiological importance, which should be taken into account when preparing fresh and slightly salted fish.

\section{References}

1. Y.G. Sleptsov, Commercial fishing in Yakutia, monograph, 35-36 (Novosibirsk, 2002)

2. V.G. Krivoshapkin et al., Nutrition is the basis for the formation of human health in the North, Sci. and Ed., 1 (Publishing House of the Academy of Sciences of the RS (Ya), 2002)

3. K.M. Stepanov, A.V. Chugunov, From ritual food to eco-nutrition today, Europ. Social Sci. J., 101(37), 302-306 (2013)

4. A.F. Kirillov, Commercial fish of Yakutia (Nauchny mir, Moscow, 2002)

5. U.M. Lebedeva A.F. Abramov, Fundamentals of rational nutrition of the population of Yakutia (Yakutsk, 2015)

6. I.E. Bykhovskaya-Pavlovskaya, Parasitological study of fish (Nauka, Leningrad, 1969)

7. T.A. Platonov, N.V. Kuzmina, I.G. Sobakina, A.N. Nyukkanov, Difillobotriids of fish of the Lena River basin, Certificate of registration of electronic material no. 2393, INIPI RAO OFERNiO, 03/01/2018.

8. A.A. Gnedov, V.M. Poznyakovsky, Commodity assessment of the quality of northern species of raw fish, Fishing, 2, 83-87 (2010)

9. A.A. Gnedov, Siberian vendace (Coregonussardinella (Valenciennes)) - quality indicators, nutritional value, Sci. and modern., 4-1, 370-375 (2010)

10. V.A. Dogel, Parasitofauna and the environment. Some issues of the ecology of parasites of freshwater fish, in Main problems of fish parasitology, 23-167 (Leningrad State University, Leningrad, 1958)

11. V.M. Poznyakovsky, Hygienic fundamentals of nutrition, safety and examination of food products (Publishing House of Novosibirsk University, Novosibirsk, 1999) 